\title{
Raveš-e tașhịhle enteqādì-ye motūn. Tehrān, Pāyā, 1379/2000, 188 p. [Méthode de textologie]
}

\section{Christophe Balaÿ}

\section{(2) OpenEdition}

1 Journals

\section{Édition électronique}

URL : http://journals.openedition.org/abstractairanica/35724

DOI : 10.4000/abstractairanica.35724

ISSN : 1961-960X

Éditeur :

CNRS (UMR 7528 Mondes iraniens et indiens), Éditions de l'IFRI

\section{Édition imprimée}

Date de publication : 15 mai 2002

ISSN : 0240-8910

\section{Référence électronique}

Christophe Balaÿ, «Raveš-e tașhịḥ-e enteqādi-ye motūn. Tehrān, Pāyā, 1379/2000, 188 p. [Méthode de textologie] », Abstracta Iranica [Ën ligne], Volume 23 | 2002, document 255, mis en ligne le 08 février 2010, consulté le 25 septembre 2020. URL : http://journals.openedition.org/abstractairanica/35724 ; DOI : https://doi.org/10.4000/abstractairanica.35724

Ce document a été généré automatiquement le 25 septembre 2020.

Tous droits réservés 


\section{Raveš-e tașhịh-e enteqādì-ye motūn. Tehrān, Pāyā, 1379/2000, 188 p. [Méthode de textologie]}

\section{Christophe Balaÿ}

L'ouvrage a été composé à partir de notes de cours suivis par l'A. auprès du Pr. Akbar Behrūz et complété par l'usage de la méthode de critique textuelle de Berstrasser éditée en persan par Dr. Jamāloddīn Šīrāziyān, Tehrān, Lak Lak, 1370/1991. La méthode de Tervat s'adresse manifestement à un lecteur étudiant chercheur désireux d'acquérir les éléments de base pour la lecture, la critique et l'édition des manuscrits. L'ouvrage est très systématique et se complète d'une brève bibliographie et d'un index.

INDEX

Thèmes : 11.1.0. Généralités

\section{AUTEURS}

CHRISTOPHE BALAŸ

IFRI- Téhéran 